Market and Competition Law Review / VOLUME III / No. 1 / APRIL 2019

\title{
Digital Economy, Big Data and Competition Law
}

\author{
Roberto Augusto Castellanos Pfeiffer ${ }^{* *}$
}

\begin{abstract}
Big data has a very important role in the digital economy, because firms have accurate tools to collect, store, analyse, treat, monetise and disseminate voluminous amounts of data. Companies have been improving their revenues with information about the behaviour, preferences, needs, expectations, desires and evaluations of their consumers. In this sense, data could be considered as a productive input.
\end{abstract}

The article focuses on the current discussion regarding the possible use of competition law and policy to address privacy concerns related to big data companies. The most traditional and powerful tool to deal with privacy concerns is personal data protection law. Notwithstanding, the article examines whether competition law should play an important role in data-driven markets where privacy is a key factor.

The article suggests a new approach to the following antitrust concepts in cases related to big data platforms: assessment of market power, merger notification thresholds, measurement of merger effects on consumer privacy, and investigation of abuse of dominant position.

In this context, the article analyses decisions of competition agencies which reviewed mergers in big data-driven markets, such as Google/DoubleClick, Facebook/ WhatsApp and Microsoft/LinkedIn.

It also reviews investigations of alleged abuse of dominant position associated with big data, in particular the proceeding opened by the Bundeskartellamt against Facebook, in which the German antitrust authority prohibited the data processing policy imposed by Facebook on its users.

\footnotetext{
* Date of Reception: 15 January 2019. Date of Acceptance: 31 January 2019.

** Professor of the Faculty of Law of University of São Paulo, Brazil. PhD (University of São Paulo). LLM (University of São Paulo). Former Commissioner of the Brazilian Competition Authority (CADE). Roberto.pfeiffer@usp.br.
} 
The article concludes that it is important to harmonise the enforcement of competition, consumer and data protection polices in order to choose the proper way to protect the users of dominant platforms, maximising the benefits of the data-driven economy.

KEYWORDS: Big Data, competition law, digital economy, privacy, abuse of dominant position.

\section{Big data: meaning and economic impact}

Big data is a theme of multidisciplinary interest, which is why many scientific research areas such as computer science, business administration, law and economics are studying its implications.

On account of this characteristic, there are multiple definitions for big data. Italian scholars of computer science have analysed 1437 abstracts of documents in different areas of knowledge mentioning the expression "Big Data" in multiple perspectives. They have coined the following definition:

"Big data represents the information assets characterized by such a high volume, velocity and variety to require specific technology and analytical methods for its transformation into value".

The European Commission, in its Communication concerning datadriven economy, has established an official definition as follows:

"The term 'Big Data' refers to large amounts of different types of data produced with high velocity from a high number of various types of sources. Handling today's highly variable and real-time datasets requires new tools and methods, such as powerful processors, software and algorithms, going beyond traditional 'data mining' tools designed to handle mainly low variety, small scale and static datasets, often manually".

\footnotetext{
${ }^{1}$ Andrea de Mauro, Mauro Greco and Micheli Grimaldi, "What is big data? A consensual definition and a review of a key research topics", 4th International Conference on Integrated Information, 2014, 10, https://www.researchgate.net/publication/265775800_What_is_Big_ Data_A_Consensual_Definition_and_a_Review_of_Key_Research_Topics.

${ }^{2}$ European Commission, Towards a Thriving Data-Driven Economy, COM (2014) 442, July 2, 2014, 4, https://ec.europa.eu/digitalagenda/en/news/communication-data-driven-economy.
} 
In this context, instead of just establishing a single definition for big data, it is important to explain its meaning. Indeed, the role of data in the economy has undergone substantial modification over the years. There was an exponential increase in the amount of data stored as a result of technological development, a greater ease in obtaining and analysing data, and a rise in the importance given to data by companies.

Therefore, it is relevant to emphasise the fundamental importance of technology. ${ }^{3}$ Computer storage capacity has been increasing year by year, as well as the improvement of data transmission mechanisms.

In other words, advances in computer technology are enabling the storage of increasingly larger amounts of data and allowing data to be collected, stored, processed, analysed and transmitted more quickly and efficiently than ever. ${ }^{4}$

Notwithstanding, big data is not only a matter of how much information firms can collect and store, but also of how it is used. Companies can make better predictions and decisions, making more-effective interventions in the market. Replacing intuition with data and rigour makes it possible for these firms to be much more agile than their competitors. ${ }^{5}$

Most authors highlight characteristics of big data starting with letter V. A very influential paper featured five data "Vs": volume, velocity, variety, verifiability and value. ${ }^{6}$

The best known of these characteristics is volume, due to the very high amount of data that can be collected and processed. As previously emphasised, technology has facilitated not only the storage of data, but also its transmission.

However, the variety of data is also very important because it allows companies to explore advertising and develop new products and services.

\footnotetext{
${ }^{3}$ Danah Boyd and Kate Crawford, "Six provocations for big data", in A Decade in Internet Time, Symposium on the Dynamics of the Internet and Society, September 21, 2011, https://ssrn.com/ abstract $=1926431$.

${ }^{4}$ Scientists estimated that the world's capacity to store information is 295 exabytes in a study published in 2011. See: Martin Hilbert and Priscila López. "The world's technological capacity to store, communicate, and compute information”, Science 332, no. 6025 (2011): 60-65, http://science.sciencemag.org/content/332/6025/60.full.

${ }^{5}$ Andrew McAfee and Erik Brynjolfsson, "Big data: The management revolution", Harvard Business Review 90, no. 10 (2012): 60-68.

${ }^{6}$ Allen P. Grunes and Maurice E. Stucke, "No mistake about it: The important role of antitrust in the era of big data", University of Tennessee Legal Studies Research Paper no. 269 (2015). https://ssrn. com/abstract=2600051.
} 
Another important aspect is verifiability: the capability to verify the veracity and accuracy of the data collected. This is of great importance to avoid drawing the wrong conclusions from the data collected.?

The speed of the collection, storage, analysis and transmission of data is also of vital importance. Consequently, velocity is another characteristic that enhances the role of data in a digital economy.

Finally, the characteristic that effectively enhances the role of data in the digital economy is its (enormous and rising) value.

Big data has a very important role in the digital economy, because firms have accurate tools to collect, store, analyse, treat, monetise and disseminate large amounts of data.

Companies have been improving their revenues with information on the behaviour, preferences, needs, expectations, desires and evaluations ${ }^{8}$ of their consumers. In this sense, data could be considered as a productive input.

The European Commission estimates that 100,000 new data-related jobs will be created in Europe by $2020,{ }^{9}$ and that the use of big data by the top $100 \mathrm{EU}$ manufacturers alone could lead to savings worth EUR 425 billion. ${ }^{10}$

The phenomenon is not recent, but has of course grown due to the intensive use of ecommerce and the variety of new services typical of the digital economy. Additionally, it is important to refer the decreasing cost for obtaining data and the increasing value that its analysis adds to business. ${ }^{11}$

There are multiple uses for personal data, which are precious not only for target advertising, but also for the improvement of services and products offered. Customer reviews, for example, are very useful for the development of new services and products. ${ }^{12}$

\footnotetext{
${ }^{7}$ Javier Andreu et al., "Big data for health", IEEE Journal of Biomedical and Health Informatics 19, no. 4 (2015): 1193-1208.

${ }^{8}$ Federico Morando, Iemma Raimondo and Emilio Raiteri, "Privacy evaluation: What empirical research on users' valuation of personal data tells us", Internet Policy Review 3, no. 2 (2014), https:// policyreview.info/articles/analysis/privacy-evaluation-what-empirical-research-users-valuationpersonal-data-tells-uu.

${ }^{9}$ European Commission, Fact Sheet Data cPPP, https://ec.europa.eu/research/industrial_technologies/pdf/factsheet-cppp_en.pdf.

${ }^{10}$ European Commission, The EU Data Protection Reform and Big Data, March 2016, https:// ec.europa.eu/epsc/publications/strategic-notes/enter-data-economy_en.

${ }^{11}$ Roland T. Rust, P.K. Kannan, and N. Peng, "The customer economics of internet privacy", Journal of the Academy of Marketing Science 30 (2002), 455-464.

${ }^{12}$ Howard A. Shelanski, "Information, innovation, and competition policy for the internet", University of Pennsylvania Law Review 161 (2013): 1665 argues that data is especially valuable to
} 
There are several activities concerning big data, such as collection, storage, synthesis, analysis and usage. ${ }^{13}$ For this reason, some authors highlight the existence of a "data value chain". ${ }^{14}$ In this context, it is possible to observe a "productive chain" that supports a variety of stakeholders and technologies. ${ }^{15}$

Consumers can benefit from new services of data-driven markets. ${ }^{16}$ However, there are many privacy concerns that may arise therefrom, such as unauthorised collection and use of personal data, invasive marketing, spam and misleading advertising.

Before analysing the tools, and in order to address privacy concerns arising from big data-driven economy, I will highlight some aspects of the two-sided markets model.

\section{Platforms and multi-sided markets}

Most digital economy services are provided through platforms which operate under the two-sided market model. In this kind of market, an intermediary (commonly referred to as a platform) enables interactions between two or more sides. ${ }^{17}$

platforms because: "(1) digital platforms generally have much greater access than conventional businesses to a broad range of information about their consumers, and (2) digital businesses may be better able to process and use that data for a variety of purposes".

${ }^{13}$ Edward Curry, "The big data value chain: Definitions, concepts, and theoretical approaches", in New Horizons for a Data-Driven Economy, ed. José Maria Cavanillas, Edward Curry and Wolfgang Wahlster (Switzerland: Springer, 2016), 29-38.

${ }^{14}$ H. Gilbert Miller and Peter Mork, "From data to decisions: A value chain for big data", IT Professional 15, no 1 (2013), 57, https://www.researchgate.net/publication/260305818_From_ Data_to_Decisions_A_Value_Chain_for_Big_Data.

${ }^{15}$ Benjamin T. Hazen et. al., "Data quality for data science, predictive analytics, and big data in supply chain management: An introduction to the problem and suggestions for research and applications", International Journal of Productions Economics 154 (2014): 72-80, https://www.sciencedirect.com/science/article/pii/S0925527314001339?via\%3Dihub.

${ }^{16}$ OECD, Data-Driven Innovation for Growth and Well-Being Interim Synthesis Report (2017), http://www.oecd.org/sti/inno/data-driven-innovation-interim-synthesis.pdf.

${ }^{17}$ Jean Tirole, Economics for the Common Goods (Princeton: Princeton University Press, 2017), 379. He defines two-sided markets as follows: "That is, a market in which an intermediary (Visa, Sony, Alphabet, Facebook, and the real estate agency) enables sellers and buyers to interact. These "platforms" bring together different communities of users seeking to interact with each other - for example, players and developers of games in the case of the videogame industry, the users of operating systems (Windows, Android, Linus or OSX on your Mac or IOS in your iPhone) and application developers; users and advertisers in the case of search engines and media; or holders of bank cards and merchants in the case of card transactions. These platforms bring both groups together and also provide a technological interface allowing them to interact". 
There are several examples of multi-sided platforms, like social networks, payment cards, search engines, marketplaces, dating clubs or applications, shopping centres, softwares, video games consoles, accommodation systems and passengers transport companies. So, most of the most popular digital economy industries operate as multi-sided platforms. ${ }^{18}$

These companies act in different segments but have a common aspect: the key importance of their users' data. Through data collection and analysis, they develop the best strategies to attract the largest possible number of users on the distinct sides of the market and promote a more effective and profitable interaction.

The platform connects the parties, often validating transactions between them. ${ }^{19}$ A good example are the credit card companies, which work as a platform to connect one side (the credit card holder) with the other side (the merchant or service provider). ${ }^{20}$

Notwithstanding, there are platforms which establish links with various sides, such as social networks like Facebook. In this context, each holder of a Facebook account can be considered as a side that exchanges publications on the platform. Another essential agent is the advertiser, who pays to advertise products and services on the Facebook platform.

The remuneration of the platform comes from price charged on both sides of the market. For example, credit cards companies usually charge both the cardholder (via membership dues) and the merchant or the service provider (via payment of a fee over the amount received).

However, the administrator often exempts the cardholder of the annual fee (in contrast to a previous financial relationship or the use of a certain amount).

There are arrangements in which the non-recovery of one side is the rule. For example, social networks and search engines charge only the advertiser. However, these services are not cost-free for consumers.

Firstly, because usually the side that pays the platform passes the amount paid to the final consumer, embedding such cost in the final price of the product sold or service rendered. In fact, the amount paid by the merchant

\footnotetext{
${ }^{18}$ David S. Evans, "Some empirical aspects of multi-sided platform industries", Review of Network Economics 2, no. 3 (2003): 191-209.

${ }^{19}$ See: Mark Armstrong, "Competition in two-sided markets", RAND Journal of Economics 37, no. 3 (2006): 668-691.

${ }^{20}$ Lapo Filistrucchi, Geradin Damien and Eric Van Damme, "Identifying two-sided markets", TILEC Discussion Paper no. 2012-008 (2012), 3, https://ssrn.com/abstract=2008661.
} 
to the credit card administrator comes embedded in the final price of the product sold to the consumer.

The same reasoning is applied if only the advertiser remunerates the platform (as occurs in social networks, in the provision of search on the internet, or in messaging or geolocation applications): the amount paid for advertising is embedded in the final price of the advertised product or service.

Furthermore, final consumers must provide something valuable, though not expressed directly in monetary terms: their personal data. The amount of data required in return, as well as the extent of the consent to the processing of data will vary in each case. Nevertheless, any kind of consumers' personal data will always be required and the transparency and the amount of its collection and processing will be a characteristic of every service integrating the quality perceived by costumers.

Consumers benefit from new services of data-driven markets, like social networks or internet search engines without paying money. Nevertheless, it is not true that the providers offer free services, since they require costumers' data in order to analyse, monetise and disseminate it.

A very important aspect of the competitive dynamics of the platforms that operate in two-sided markets is the fact that they benefit from network externalities, i.e., the positive effects that are generated when a large number of economic agents use the network operated by the platform. In other words, the more agents use the network on either side, the greater the value the network.

One good example is search engine service. What the user expects is the appearance of good search results. For example, web pages that explain the functioning of a product the consumer wishes to purchase. The faster and more accurate the search results, the greater will be the user satisfaction.

Search engine services work with algorithms that select the appearance of the search results. The higher the number of users, the better the search service, which "learns" from users' experience. Therefore, in the example chosen, the more users do product research, the more search results will be improved.

Finally, advertisers want the largest possible number of users watching the advertising of their products and services. It is logical that they prefer search engine platforms that have the greatest number of users, being willing to pay a higher price.

Another example is the service provided by transportation network companies. Consumers benefit from it if there is a large supply of drivers, 
as this may provide faster transport. Drivers want the largest possible number of consumers on the other side of the market, since it will increase the demand for their services.

Thus, network effects tend to foment concentrated markets, because platforms benefit from a high number of users, making it much more difficult for competitors with small number of users.

This explains the existence of markets with a dominant company, as is the case with search engine services, social networking, messenger services, marketplaces, etc.

In this context, antitrust authorities should dedicate special attention to markets with such characteristics, mainly when analysing mergers and conducts involving dominant firms. ${ }^{21}$

This reality makes it difficult to assess effects of anti-competitive mergers or conducts involving service providers in the digital economy. ${ }^{22}$ This is because often the disadvantage can occur exclusively on one side of the market. So, it is very important to analyse merger effects on both sides of the market.

Normally, antitrust agencies analyse the impact on the side that pays for the product or service and could suffer negative effects with the concentration subject to merger control. ${ }^{23}$

When mergers reduce the welfare of the zero-price side, it becomes more difficult for antitrust authorities to assess the negative impact, since the tools used by competition authorities have been developed to analyse the price effects. Therefore, competition agencies have substantial difficulties in analysing impact in other dimensions, such as the quality of the service provided.

This characteristic heavily hinders assessment by competition authorities, because the traditional instrumental analysis of mergers is based on

\footnotetext{
${ }^{21}$ Lina Khan, "Amazon's antitrust paradox". Yale Law Journal 126, no. 3 (2016-2017): 712-805, https://www.yalelawjournal.org/pdf/e.710.Khan.805_zuvfyyeh.pdf.

${ }^{22}$ Bernard Caillaud and Bruno Jullien, "Chicken \& egg: Competition among intermediation service providers”, RAND Journal of Economics 34, no. 2 (2003), https://ssrn.com/abstract=406691.

${ }^{23}$ See: Maurice E. Stucke and Ariel Ezrachi, "Looking up in the data-driven economy", University of Tennessee Legal Studies Research Paper no. 333 (2017), 1, https://ssrn.com/abstract=2975510. The authors highlight that "the super-platforms can squeeze millions of sellers, including photographers, photojournalists, writers, journalists and musicians. Our competition laws deal with this kind of buyer power. These concerns, however, are often low on the enforcement agenda due to the indirect effects on 'consumer welfare', which is often measured by the price you pay for the goods or service. So, if we stream the YouTube video ostensibly for 'free', the assumption is that our welfare is maximized. In the digital age, as this essay argues, that urgently needs to change".
} 
the investigation of the effects on the price. For example, the "hypothetical monopolist" test is focused on substitution in response to a small but significant and non-transitory increase in price to define the relevant market.

Price is the central element of the last phase of the merger control process. Indeed, if it is found that the merger restricts competition in the relevant market with significant barriers to entry, competition authorities must investigate the net effects of the concentration. In this phase, antitrust authorities analyse whether restrictions on competition are higher or lower than the efficiencies generated by the merger.

At this stage, the most accepted test is the price standard, which simulates the behaviours of the post-merger price. Compensatory efficiency must be either sufficiently high for the post-merger price to remain unchanged, or lower than the pre-merger price.

In fact, the 2010 US Horizontal Merger Guidelines adopted the consumer welfare criterion, establishing that mergers cannot be approved if they generate price increase. ${ }^{24}$

The European "Guidelines on the assessment of horizontal mergers under the Council regulation on the control of concentrations between undertakings" make it clear that efficiencies must be of a compensatory nature: they should overcome the harmful effects brought by the reinforcement of the dominant position and cannot harm consumers. The document establishes that efficiency gains must benefit consumers, be mergerspecific, and be verifiable. ${ }^{25}$

Brazilian Competition Law allows efficiency gains to be used as a justification for mergers and acquisitions that restrain competition but, on the other hand, it requires the transfer of a relevant part of the benefits resulting from economics efficiencies to consumers (art. 88, \$6, II of Law 12.529/2011). Thus, in coherence with Law 12.529/2011, Brazilian horizontal mergers guidelines ("Guideline H") adopt the criterion of preserving consumer welfare in the analysis of efficiencies. ${ }^{26}$

\footnotetext{
${ }^{24}$ See: Russell W. Pittman, "Consumer surplus as the appropriate standard for antitrust enforcement", Competition Policy International 3, no. 2 (2007): 205-224, https://ssrn.com/ abstract $=1075463$.

${ }^{25}$ European Commission, Guidelines on the Assessment of Horizontal Mergers under the Council Regulation on the Control of Concentrations between Undertakings, (2004/C 31/03), paragraph 78, https://eur-lex.europa.eu/legal-content/EN/ALL/?uri=CELEX\%3A52004XC0205\%2802\%29.

${ }^{26}$ Conselho Administrativo de Defesa Econômica, Guia para Análise de Atos de Concentração Horizontal, (2006), 45-46, http://www.cade.gov.br/acesso-a-informacao/publicacoes-institucionais/guias_do_Cade/guia-para-analise-de-atos-de-concentracao-horizontal.pdf/view.
} 
In this context, a merger that could lead to price increase cannot be allowed in Europe, the United States or Brazil.

If no price is charged, though, how can the effects caused by a merger be analysed? A possible answer would be to investigate the effects on the privacy policy of the merged companies.

A first justification that can be offered to support this hypothesis is that the privacy policy integrates the quality of the service or product affected by the merger.

Additionally, it is also possible to affirm that the data collected and the consent to its treatment would integrate the non-monetary counterpart provided by the consumer. In this context, a second justification is that the "price" paid by consumers could be affected by the merger.

A major obstacle faced by competition authorities is that the analysis methodology is excessively focused on the investigation of the consequences of the merger on the monetary price. ${ }^{27}$ The difficulty is not restricted to the data-driven economy, because even in relation to traditional products or services the use of different analytical methodologies is claimed.

For example, the use of a consumer choice approach is advocated in cases where the price is not the main competitive variable of a given market. Its defenders sustain that the central objective of antitrust would be to protect the options essential for the consumer, related not only to price, but also to variety, innovation and quality. Such a paradigm would be applicable in non-price competition markets, especially in regulated sectors subject to tariffs, and in markets in which creativity and innovation are more relevant to competitiveness than price. ${ }^{28}$

Consequently, antitrust authorities should avoid the mistake of only analysing the impact on the price charged to one side assuming that there will be no effect on the other side. ${ }^{29}$

\footnotetext{
${ }^{27}$ Competition authorities have developed tools to investigate whether economic efficiencies emerging from concentrations benefit consumers or not. However, they do not usually analyse concerns related to non-economic aspects. See, with regard to the European experience, Inge Graef, "Blurring boundaries of consumer welfare", in Personal Data in Competition, Consumer Protection and Intellectual Property Law, ed. Mor Bakhoum et al. (Berlin: Springer, 2018), 121-152.

${ }^{28}$ Neil W. Averitt and Robert H. Lande, "Using the 'consumer choice approach' to antitrust law", Antitrust Law Journal 74 (2007): 187 and 196.

${ }^{29}$ Maurice E. Stucke and Allen P. Grunes, Big Data and Competition Policy (Oxford: Oxford University Press, 2016), 5. Authors affirm that: "Quality, including privacy protection, will be an important aspect of non-price competition. When competition agencies solely focus on the 'paid'
} 
As already exposed, even if there is direct payment only by one side, the other side is also charged, since the amount paid to the platform is embedded into the final price of the product or service. ${ }^{30}$

In addition, there is an important direct payment of consumers to the platform: the collection and processing of their personal data. In this sense, it is possible to consider data as a new currency.

There is also another way for consumers to "pay" for the service or product delivered by the platform: their attention. ${ }^{31}$ Indeed, consumers' attention is fundamental to the advertising market, which generates a positive externality: the more consumers use the platform, the more attractive it will be for vendors and advertisers. ${ }^{32}$ There is a clear network effect: platforms with a large number of users (or viewers) are more attractive to advertisers and tend to be dominant. ${ }^{33}$

The possibility of conflict of interest is another argument to support the thesis that antitrust authorities must analyse effects on all sides. For example, if the merger reduces the offer of platforms, it may eliminate incentives for less aggressive practices of data collection and treatment.

Imagine that, for example, the dominant platform acquires a smaller competitor that adopts practices to collect less data and not process the data collected, adopting a privacy by design model. ${ }^{34}$ It is probable that the dominant platform adopts a more extensive data collection and processing, including its transference to third parties.

Eventually, many consumers choose the smaller platform to preserve their privacy. Thus, the merger will bring a disadvantage to the consumer: the elimination of a competitor that has better practices in relation to data collection and processing.

advertising side of these multi-sided markets, and ignore the merger's impact on the 'free' side, both consumers and advertisers are harmed".

${ }^{30}$ Daniel L. Rubinfeld and Michal S. Gal, "The hidden costs of free goods: Implications for antitrust enforcement", Antitrust Law Journal 80 (2016): 521-562.

${ }^{31}$ Tim Wu, The Attention Merchants: The Epic Scramble to Get Inside Our Heads (New York: Alfred A. Knopf, 2016), 16.

${ }^{32}$ David S. Evans, "Attention to rivalry among online platforms and its implications for antitrust analysis", Coase-Sandor Institute for Law \& Economics Working Paper no. 627, (2013), 5, https:// chicagounbound.uchicago.edu/cgi/viewcontent.cgi?article=1067\&context=law_and_economics.

${ }^{33}$ John M. Newman, "Antitrust in zero-price markets: Foundations", University of Pennsylvania Law Review 164, no. 1 (2015): 174.

${ }^{34}$ The concept of privacy by design is developed by Ann Cavoukian, Privacy by Design in Law, Policy and Practice: A White Paper for Regulators, Decision-Makers and Policy-Makers, (2011). http://www.ontla.on.ca/library/repository/mon/25008/312239.pdf. 
Obviously, such privacy by default practice is part of the quality of the service provided by the platform, and in this hypothetical case the merger would lead to a negative effect on quality.

Platforms are large data gatherers, undertaking various activities related to data processing, such as analysis, transmission to third parties, customisation and conversion into targeted advertising, among others.

A merger that strengthens the dominant position of companies involved can reduce incentives for the adoption of privacy policies that favour consumers. Antitrust authorities should investigate if the restriction to competition will bring negative effects on data processing consistent with the withdrawal of incentives to adopt more consumer-friendly privacy policies. $^{35}$

Therefore, privacy policy is a central aspect in the relationship of the platform with its users which deserves special attention on the part of competition policy authorities, which should use methods other than traditional analysis in cases where there is no financial counterpart.

\section{Assessment of market power}

Market power is a company's position of preponderance in the relevant market, influencing the conduct of competitors or subtracting their influence through an independent conduct. ${ }^{36}$

Market power is usually associated with a company's capacity to influence a competition dynamic in order to be able to set its prices above the marginal cost. ${ }^{37}$

Normally, competition law uses the term dominant position as a synonym of market power and establishes objective criteria to measure its existence.

Brazilian competition law, for example, defines dominant position as follows:

\footnotetext{
${ }^{35}$ Maurice E. Stucke and Allen P. Grunes, Big Data and Competition Policy, 51 affirm that: "The fundamental problem in these (data-driven) markets is that consumers lack viable alternatives. Here we see the core concern of competition policy' - namely the accumulation of market power - intersect with privacy concerns. The reason why market forces have not yielded the privacy protections that individuals desire is the absence of meaningful competition".

${ }^{36}$ Paula Forgioni, Os Fundamentos do Antitruste (São Paulo: Revista dos Tribunais, 2018), 28.

${ }^{37}$ Jean Tirole, Economics for the Common Good, 357. The author coined the following definition: "market Power - that is, a firm's ability to set its prices substantiality above its costs or to offer poorquality services without losing many customers”.
} 
"A dominant position is assumed when a company or group of companies is able to unilaterally or jointly change market conditions or when it controls $20 \%$ (twenty percent) or more of the relevant market, provided that such percentage may be modified by CADE ${ }^{38}$ for specific sectors of the economy". ${ }^{39}$

Only the abuse of dominant position is prohibited in Brazil. In accordance with $₫ 1$ of article 36 of the Brazilian Competition Law, achieving dominance in a market by a natural process and by being the most efficient economic agent in relation to competitors does not characterise an antitrust violation.

Aligned with Brazil, EU competition law does not forbid holding a dominant position, since it can be obtained by legitimate business strategies and merits. Article 102 of the Treaty on the Functioning of the European Union (TFEU) prohibits only the abuse, not the holding of a dominant position. ${ }^{40}$

Therefore, a dominant firm could perfectly compete on the merits, ${ }^{41}$ but has a special responsibility to avoid distortion of competition on the market. ${ }^{42}$

Although there is no definition in article 102 (ex-article 82 of the Treaty), the Court of Justice of the European Union has established the following concept of dominant position:

“(..) relates to a position of economic strength enjoyed by an undertaking, which enables it to prevent effective competition being maintained on the relevant market by affording it the power to behave to an appreciable extent independently of its competitors, its customers and ultimately of the consumers". ${ }^{43}$

\footnotetext{
${ }^{38}$ Brazilian competition authority (CADE - Administrative Council for Economic Defense).

${ }^{39}$ Article 36, $\$ 2$ of Law no. 12.529 of November 30, 2011 (Brazilian Competition Law).

${ }^{40}$ European Commission, Guidance on the Commission's enforcement priorities in applying Article 82 of the EC Treaty to abusive exclusionary conduct by dominant undertakings, (2009/C 45/02), https://eur-lex.europa.eu/legal-content/EN/ALL/?uri=CELEX\%3A52009XC0224\%2801\%29.

${ }^{41}$ Nicolas Petit, "From formalism to effects? - The Commission's communication on enforcement priorities in applying article $82 \mathrm{EC",} \mathrm{World} \mathrm{Competition:} \mathrm{Law} \mathrm{and} \mathrm{Economics} \mathrm{Review,} \mathrm{forthcoming.}$ (2009): 1-19, https://ssrn.com/abstract=1476082.

${ }^{42}$ Thomas Eilmansberger, "How to distinguish good from bad competition under article 82 EC: In search of clearer and more coherent standards for anti-competitive abuses", Common Market Law Review 42 (2005): 129-177.

${ }^{43}$ Judgment of 14 February 1978, United Brands Company and United Brands Continental BV v. Commission, Case 27/76, ECLI:EU:C:1978:22, paragraph 65, and Judgment of 13 February 1979, Hoffmann-La Roche \& Co. AG v. Commission, Case 85/76, ECLI:EU:C:1979:36, paragraph 38.
} 
Normally, market power assessment is associated with market share. In this context, a firm holds a dominant position whether it has a significant share of the relevant market. However, market power is not an absolute term, but a matter of degree that will depend on the circumstances of each case. $^{44}$

There are situations in which market share would not be a good proxy to measure market power. For example, the hypothesis of a new entrant in the relevant market which has a dominant position in another market vertically integrated.

Yet, the purpose of the topic is not to analyse all the possibilities of market power measurement ${ }^{45}$ but to support the argument that a dominant position cannot be established on the sole basis of large market shares.

There are other elements that should be analysed: in data-driven markets, it is important to consider companies' ability to collect and process data as an element of market power.

Nevertheless, there are scholars who understand that data collection cannot be considered as a source of dominant position, because data is ubiquitous, inexpensive, ${ }^{46}$ non-exclusive and non-rivalrous. ${ }^{47}$ In this context, data control cannot be considered a barrier to entry because it can easily be collected. ${ }^{48}$

On the other hand, a joint report by the French Autorité de la Concurrence and the German Bundeskartellamt offers several arguments defending that data can be a source of market power. The essay highlights the importance of data variety to provide competitiveness on the market, understanding that data processing could result in entry barriers when

\footnotetext{
${ }^{44}$ Office of Fair Trade, Assessment of Market Power, December $1^{\text {st }}, 2004$, https://assets.publishing. service.gov.uk/government/uploads/system/uploads/attachment_data/file/284400/oft415.pdf.

${ }^{45}$ For example, linkage of market failures, in special imperfect information, with dominant position. See: Robert H. Lande, "Market power without a large market share: The role of imperfect information and other 'consumer protection' market failures”. American Antitrust Institute Working Paper no. 07-06, (2007): 1-18, https:/www.justice.gov/atr/market-power-without-largemarket-share-role-imperfect-information-and-other-consumer-protection.

${ }^{46}$ Catherine Tucker, "The implications of improved attribution and measurability for antitrust and privacy in online advertising markets”, George Mason Law Review 20 no. 4 (2013): 1025-1034.

${ }^{47}$ D. Daniel Sokol and Roisin E. Comerford, "Antitrust and regulating big data", George Mason Law Review 23, no. 5 (2016): 1129-1162.

${ }^{48}$ Darren S. Tucker and Hill Wellford, "Big mistakes regarding big data", The Antitrust Source, (December 2014): 1-12, https://www.americanbar.org/content/dam/aba/publishing/antitrust_ source/dec14_tucker_12_16f.authcheckdam.pdf.
} 
new entrants are unable either to collect data or to buy the same kind of data. ${ }^{49}$

Moreover, in several data-driven markets, companies having the ability to collect and process data more efficiently than their competitors as one of their competitive differentials quickly obtain a dominant position. ${ }^{50}$

Data collection and processing can be a vehicle for price discrimination, facilitate collusion when companies use the data to fix prices with algorithms, ${ }^{51}$ and contribute to the stability and prevalence of cartels that use big data. ${ }^{52}$

There is also intense use of data to improve the performance of companies, to differentiate themselves from competition and to develop new products and services.

In this context, it is important to discuss whether data collection, storage and processing can be an expression of economic power. ${ }^{53}$

There is no administrative or jurisdictional case in Brazil that has discussed data as a source of market power. In addition, there is no proposal to change the Brazilian legal definition of dominant position.

On the other hand, Germany has amended its legislation to stipulate new hypotheses of market power related to data collection and storage.

\footnotetext{
${ }^{49}$ Autorité de la Concurrence and Bundeskartellamt. Competition Law and Data (2016), 23. https://www.bundeskartellamt.de/SharedDocs/Publikation/DE/Berichte/Big\%20Data\%20Papier. pdf?__blob=publicationFile\&v=2.

${ }^{50} \mathrm{~A}$ good example is the company Wase. According to the British antitrust authority, it was the ability to collect and process data more quickly and efficiently than competitors that gave the company a significant market share in mapping service in the United Kingdom, motivating the high value of its Acquisition by Google. See: Office of Fair Trade, Completed acquisition by Motorola Mobility Holding (Google, Inc.) of Waze Mobile Limited, ME/6167/13, November 11, 2013, https:// assets.publishing.service.gov.uk/media/555de2cfed915d7ae2000027/motorola.pdf.

${ }^{51}$ The focus of this article are the consequences of holding a large amount of data in the analysis of unilateral mergers and unilateral conducts. Therefore, it will not address the important topic of facilitation of collusions through data exchange, a theme that has received increasing attention from the antitrust authorities. On the topic see, for example: OECD, Algorithms and Collusion: Competition Policy in the Digital Age (2017), www.oecd.org/competition/algorithms-collusioncompetition-policy-in-the-digital-age.htm.

${ }^{52}$ Simonetta Vezzoso, "Competition policy in a world of big data", in Research Handbook on Digital Transformations, ed. F. Xavier Olleros and Majlinda Zhegu (Cheltenham: Edward Elgar, 2016), 400, https://ssrn.com/abstract=2717497.

${ }^{53}$ Marc Bourreau, Alexandre de Streel and Inge Graef, "Big data and competition policy: Market power, personalised pricing and advertising", Centre on Regulation in Europe (February 16, 2017): 7-61, https://ssrn.com/abstract=2920301.
} 
Indeed, Germany enacted the ninth Amendment of the Federal Act against Restraints of Competition, which entered into force on $9^{\text {th }}$ June 2017. One of the new provisions establishes data as a source of market power. Indeed, $\$ 18$ of the German Act defines the following hypotheses of market dominance:

"(3a) In particular in the case of multi-sided markets and networks, in assessing the market position of an undertaking account shall also be taken of:

1. direct and indirect network effects,

2. the parallel use of services from different providers and the switching costs for users,

3. the undertaking's economies of scale arising in connection with network effects,

4. the undertaking's access to data relevant for competition,

5. innovation-driven competitive pressure".

The amendment updated the current German law to address typical concerns of the digital economy - the German Act, therefore, refers to network effects, economies of scale, costs for consumers, pressures related to technological innovations and, notably, access to data relevant for competition as factors that characterise market domination.

Furthermore, there is express reference to the increase of platforms' market power by network effects. When referring to switching costs, German law cares about the two sides linked by a platform with a dominant position. Such a perspective reinforces the argument that the antitrust authority needs to consider the impact on both sides of the market for possible mergers or conducts involving platforms with a dominant position. ${ }^{54}$

\footnotetext{
${ }^{54}$ Beiten Burkhardt, “The new German competition law in a nutshell”, Lexology, June 26, 2017, https://www.lexology.com/library/detail.aspx?g=535d2bda-4598-413d-86c6-05b592b1c7b5. The author clarifies that: "However, there was a bit of a debate in Germany whether a market without direct monetary considerations is a market at all. The amendment's answer is 'Yes, a market without direct monetary considerations is a market for competition law purposes'. This clarification strengthens the legal basis for investigating abusive practices in platform markets".
} 


\section{Merger notification threshold}

There are acquisitions with potential impact on competition which skip merger control for not meeting the notification thresholds. Such circumstance is not unique of the digital economy or companies operating with big data; however, it assumes a larger dimension within such markets, characterised by innovation and rapid expansion of the leaders.

For example, the merger between Facebook and WhatsApp did not meet the thresholds in several national jurisdictions of Europe given that the companies involved had low revenues. The European Commission reviewed the merger only because there had been meeting notification thresholds in more than three countries of the European Union.

In Brazil, the mentioned merger did not meet the legal notification thresholds and was therefore not reported to the antitrust authority (Administrative Council for Economic Defense - CADE).

Brazilian notification thresholds are based exclusively on the combined annual local turnovers of the companies involved in the merger.

Thus, in accordance with article 88 of Law no. 12.529, enacted in November 30, 2011, a merger must be submitted to the Brazilian Federal antitrust authority if: I - at least one of the groups involved in the transaction has registered, in the last balance sheet, annual gross sales or total turnover in the country, in the year preceding the transaction, equivalent or superior to four hundred million reais ( $\mathrm{R} \$ 400,000,000.00$, or US\$100,000,000,00); and cumulatively, II - at least another group involved in the transaction has registered, in the last balance sheet, gross annual sales or total turnover in the country, in the year preceding the transaction, equivalent to or greater than thirty million reais ( $\mathrm{R} \$ 30,000,000.00$ or US $\$ 8,000,000.00$ ).

Brazilian law allows an inter-ministerial decree of the Ministries of Finance and Justice to modify the turnover amount. On 30 May 2012, Decree no. 994 was enacted, which increased the combined notification thresholds to seven hundred and fifty million reais ( $R \$ 750,000,000.00$ or US $\$ 200,000,000.00)$ for the one group and seventy-five million reais ( $\mathrm{R} \$$ $75,000,000.00$ or US\$200,000.00) for the other group involved.

Several other mergers which could have an impact on competition were not notified because they did not fit the criteria for notification, since they had no significant revenues registered in Brazil in the specific moment of the transaction.

In addition, there has been the phenomenon of acquisitions of start-up companies with low income by larger companies. In these cases, normally 
the combined threshold criteria are not met, and such mergers are not notifiable, therefore not being subject to review by the Brazilian competition authority (CADE).

Such blind spots in merger notification rules are especially verifiable within the digital economy sector due to the dynamism in which new market niches appear and start-ups have a fertile field for growth and are frequently acquired by larger companies before they reach a high turnover.

In Brazil, although there are scholars who express concern about the topic, especially in relation to the strategy of large companies acquire small firms with revenues below the minimum parameter and thus do not need to notify the operation ${ }^{55}$, there is no initiative in the Brazilian Congress for modification so far.

So, even if it is not an exclusive problem, there is no doubt that the blind spots of the threshold notification rules particularly affect relevant markets associated with the digital economy and, even more specifically, those that are big-data driven. ${ }^{56}$

In Europe, it is worth noting the recent modification carried out in German legislation, whose main alteration was the addition of the value of the transaction.

One of the amendments to the Act against Restraints of Competition added a transaction value threshold. In accordance with $\$ 35$ of the German Law, which regulates the scope of application of the control of Concentrations:

"(1) The provisions on the control of concentrations shall apply if in the last business year preceding the concentration

1. the combined aggregate worldwide turnover of all the undertakings concerned was more than EUR 500 million, and

2. the domestic turnover of at least one undertaking concerned was more than EUR 25 million and that of another undertaking concerned was more than EUR 5 million.

\footnotetext{
${ }^{55}$ Ana Frazão, "Big data eimpactos sobre a análise concorrencial: Preocupações quejá se vislumbram no cenário atual". Jota, 7 February 2018. https://www.jota.info/?pagename=paywall\&redirect_ to=//www.jota.info/opiniao-e-analise/colunas/constituicao-empresa-e-mercado/big-data-eimpactos-sobre-analise-concorrencial-2-07022018.

${ }^{56} \mathrm{Tim} \mathrm{Wu}$, "Blind spot: The attention economy and the law", Antitrust Law Journal, forthcoming (2017): 2-40, https://scholarship.law.columbia.edu/faculty_scholarship/2029.
} 
(1a) The provisions on the control of concentrations shall also apply if

1. the requirements of paragraph 1 no. 1 are fulfilled,

2. in the last business year preceding the concentration a) the domestic turnover of one undertaking concerned was more than EUR 25 million and

b) neither the target undertaking, nor any other undertaking concerned achieved a domestic turnover of more than EUR 5 million,

3. the consideration for the acquisition exceeds EUR 400 million and

4. the target undertaking pursuant to no. 2 has substantial operations in Germany".

The new threshold allows merger control in Germany to apply to acquisitions of start-up companies with innovative business models which have a low turnover at the time of the merger but have potential to assume an important position in the market in the future.

The new German criterion is inspired by the United States of America, whose legislation adopts two types of notification thresholds: the "size-ofperson" test and the "size-of-transaction" test. The value of the thresholds is adjusted annually in accordance with changes in the gross national product. The revised thresholds announced by the Federal Trade Commission in 2018 are: 1 - Acquisitions valued at $\$ 84.4$ million or less are not subject to notification; 2 - transactions valued at more than $\$ 337.6$ million must be notified regardless of the size of companies; and 3 - merges valued between $\$ 84.4$ million and $\$ 337.6$ million are reportable only if the size-ofperson test is met. ${ }^{57}$

Austria has also included a similar update of its merger control thresholds in its planned legislative amendment package.

The new amended regime, which is in force since 1 November 2018, introduces an additional transaction value test. Besides the turnover rule, a transaction must be submitted to the Austrian Cartel Office if in the business year preceding the transaction:

"The combined worldwide turnover of the undertakings exceeds $€ 300$ million (US\$352.1 million); and

\footnotetext{
${ }^{57}$ Federal Trade Commission, Revised Jurisdictional Thresholds for Section 7A of the Clayton Act, January 29, 2018, https://www.ftc.gov/system/files/documents/federal_register_notices/2018/01/ revised_jurisdiction_7a_1-29-18.pdf.
} 
The combined Austrian turnover of the undertakings exceeds $€ 15$ million (US\$17.6 million); and

The value of the consideration paid in return for the transaction exceeds $€ 200$ million (US\$234.7 million); and

The target is active in Austria to a significant extent".

Thus, the amendment passed in Austrian and German antitrust laws allows National Competition Authorities to pursue a more active role in merger control of big data companies. The introduction of the size-oftransaction test allows competition authorities to review acquisitions of small companies carried out by dominant firms, as well as the entry operation in the national geographic market of a company with a dominant position in its original geographic market, if these operations meet the new notification thresholds.

\section{Big Data merger control}

A very controversial issue is whether the analysis of the effects on consumer privacy should integrate the review of mergers involving big data companies, i.e., firms that act as data gatherers and data processors in the development of their activities.

There is a wide divergence as regards the scope of the analysis of antitrust authorities in big-data-driven mergers. Should the analysis of competition authorities reach concerns related to consumer privacy? Alternatively, should merger control analyse only possible effects of the merger on the price of services or products of big data companies?

\subsection{Pros and cons of privacy on merger control}

A strong argument against a proactive surveillance of competition authorities in data protection issues is the large list of benefits brought by Big Data. ${ }^{58}$ In this regard, antitrust policy would not be appropriate for dealing with privacy concerns. Consumer protection or data protection laws (if existing) would be better tools for addressing big data privacy issues. ${ }^{59}$

\footnotetext{
${ }^{58}$ Darren S. Tucker and Hill Wellford, "Big mistakes regarding big data", The Antitrust Source, (2014), https://www.americanbar.org/content/dam/aba/publishing/antitrust_source/dec14_ tucker_12_16f.authcheckdam.pdf. The authors highlight that: "Big data and analysis increase economic output, reduce crime, improve public health and safety, increase voter turnout, boost energy efficiency, improve weather forecasts, and enhance agricultural yields".

${ }^{59}$ D. Daniel Sokol and Roisin E. Comerford, "Antitrust and regulating big data", George Mason Law Review 23, no. 5 (2016): 1129-1162.
} 
A counterargument is that consumers pay by delivering their personal data to use services provided by dominant big data companies only because they have no viable alternatives. Firms with a dominant position which extract data from their consumers would have little incentive to invest in privacy protections if their competitors were too small. In this context, firms with strong market power would not suffer competitive pressure significant enough to discipline their misconduct. ${ }^{60}$

Another argument is that there is asymmetric information in the relationship between consumers and platforms, and consumers face a bounded rationality. These aspects show that despite the importance of the "informed decision" as a fundament of data protection regulation, this principle has its limits and does not protect consumers in all situations. ${ }^{61}$

The competence to protect privacy belongs to data protection authorities. However, privacy policies, which include transparency and methods used by companies to obtain consumer consent to data collection, as well as the quantity of data required, are a competitive differential.

In other words, data-driven companies have different privacy policies. In this context, it is not true that necessarily all businesses will adopt the same transparency and scope of data processing. ${ }^{62}$

Companies also compete in how and what kind of consumer data they capture, as well as in the indiscriminate or restricted use of the data collected. A good example comes from the search engines market: a small company can differentiate its services from the dominant firm by offering users more privacy. ${ }^{63}$

\footnotetext{
${ }^{60}$ See: Pamela Jones Harbour and Tara Isa Koslov, "Section 2 in a Web 2.0 World: An expanded vision of relevant product markets", Antitrust Law Journal 76 (2010): 785.

${ }^{61}$ Bertin Martens, "An economic policy perspective on online platforms", Institute for Prospective Technological Studies Digital Economy Working Paper 2016/05 (2016): 1, https://ec.europa.eu/jrc/ sites/jrcsh/files/JRC101501.pdf. The author understands that "widespread market failure of privacy-informed decision by consumers could pave the way for regulatory intervention".

${ }^{62}$ The following articles argue that firms may compete by offering more transparent privacy policies: David S. Evans, "The online advertising industry: Economics, evolution, and privacy", The Journal of Economic Perspectives 23, no. 3 (2009): 37-60, and Scott J. Savage \& Donald M. Waldman, "Privacy tradeoffs in smartphone applications", Economic Letters 137 (2015): 171-175.

${ }^{63}$ For instance, Duckduckgo is a search engine that advertises privacy as its main characteristic. The firm promises that will not track their users, affirming that: "Too many people believe that you simply can't expect privacy on the Internet. We disagree and have made it our mission to set a new standard of trust online". See: https://duckduckgo.com/about.
} 
In this context, privacy policy could be considered as a non-price element of big data-driven markets, integrating the concept of service or product quality. ${ }^{64}$

Two-sided markets are predominant in the digital economy, and usually the consumer side is not directly charged in financial terms. Still, consumers pay an indirect remuneration through their personal data collection and processing.

Big data companies collect and process data as an essential part of their business model, ${ }^{65}$ which reinforces the argument that privacy could be considered a form of non-price competition. ${ }^{66}$

There is a subtle, but important difference between a mandate to protect privacy and a task to examine whether a restrictive merger that affects competition will have a negative impact on data collection and processing.

It is not a crusade to transform a competition agency into a data protection authority, only an argument to include the assessment of privacy restrictions in the review of problematic mergers between big data companies.

In cases of merger reviews involving big data companies which could limit competition, it seems important to analyse not only the possible effects on the price alone, but also to investigate the consequences to privacy policies.

\subsection{Analysis of jurisprudence}

The Brazilian competition authority (CADE) has not discussed privacy concerns in merger control. One of the factors that have contributed to the absence of this debate is the fact that the most famous worldwide big data mergers did not meet Brazilian notification thresholds.

In Europe, there are several examples of big data mergers reviewed by the European Commission. In two of them, the European Commission discussed the relevance of the investigation on alleged effects on privacy policies: Google/DoubleClick and Facebook/WhatsApp.

\footnotetext{
${ }^{64}$ Neil W. Averitt and Robert H. Lande, "Using the 'consumer choice' approach to antitrust law", Antitrust Law Journal 74 (2007): 175-264. The authors highlight that: "Market power also can distort non-price attributes anticompetitive even if price is unaffected".

${ }^{65} \mathrm{Tim} \mathrm{Wu}$, "It's time to break up Facebook", The Verge, April 9, 2018. https://www.theverge. com/2018/9/4/17816572/tim-wu-facebook-regulation-interview-curse-of-bigness-antitruste.

${ }^{66}$ Maureen K. Ohlhausen and Alexander P. Okuliar, "Competition, consumer protection and the right (approach) to privacy”, Antitrust Law Journal 80, no. 1 (2015): 126.
} 
The European Commission cleared the proposal merger, adopting the understanding that the acquisition would not raise competition concerns under competition law.

During the investigation in Europe, competition and privacy concerns arose focused mainly on the combination of the databases held by Google and DoubleClick, as well as on whether the company would have more incentives to track customer online behaviour for targeting purposes. The European Commission limited its analyses to an antitrust point of view and concluded that the merged database was unlikely to produce harmful effects on competition, either in the market for ad serving technology or in the market for online advertising.

The most well-known case is the acquisition of WhatsApp by Facebook. The European Commission defined three relevant markets: (1) consumer communications services, (2) social networking services, and (3) online advertising services. The Commission considered that the transaction did not give rise to serious doubts about its compatibility with the internal market with respect to all three relevant markets, and decided, therefore, not to oppose the transaction and to declare it compatible with the internal market and the EEA Agreement. ${ }^{67}$

A very important aspect of the decision was that the European Commission recognised the importance of privacy policy as a parameter of competition in consumer communications services. ${ }^{68}$

Notwithstanding, the European Commission affirmed that it would not investigate the privacy issues arising from the operation, namely whether the merger would increase the ability of Facebook to concentrate the control of personal data. The Commission understood that such investigation was not a task for the antitrust authority, as noted in the following excerpt of the reasoning adopted by the Commission:

"(164) For the purposes of this decision, the Commission has analysed potential data concentration only to the extent that it is likely to strengthen Facebook's position in the online advertising market or in any sub-segments thereof. Any privacy-related concerns flowing from the increased concentration of data within the control of Facebook as a result of the

\footnotetext{
${ }^{67}$ European Commission, Case M.7217, Facebook/WhatsApp, October 3, 2014 http://ec.europa.eu/ competition/mergers/cases/decisions/m7217_20141003_20310_3962132_EN.pdf.

${ }^{68}$ European Commission, Case M.7217, paragraphs 87 and 102, and footnote 79.
} 
Transaction do not fall within the scope of the EU competition law rules but within the scope of the EU data protection rules". ${ }^{69}$

For its part, in the Asnef-Equifax Case, the Court of Justice of the European Union underlined that data protection is not a competition law matter:

"63 Furthermore, since, as the Advocate General observed, in substance, at point 56 of his Opinion, any possible issues relating to the sensitivity of personal data are not, as such, a matter for competition law, they may be resolved on the basis of the relevant provisions governing data protection" ${ }^{70}$

Although the cited decisions did not include concerns related to personal data protection among the objectives of the competition policy, there are new positions pointing out to a convergent enforcement of the two spheres.

In this regard, the most important precedent in merger control is the acquisition of LinkedIn by Microsoft. The European Commission reinforced its understanding that privacy is an important parameter of competition in data-driven markets and expressed concern that the operation could restrict consumer choice and marginalise competitors with more user-friendly privacy policies than LinkedIn. ${ }^{71}$

The Commission decided not to oppose the Microsoft/LinkedIn merger, subject to full compliance with the obligations contained in the final commitments, which established suitable remedies that addressed anticompetitive conglomerate effects found by the Commission during its investigation. ${ }^{72}$

\footnotetext{
${ }^{69}$ European Commission, Case M.7217, paragraph 164.

${ }^{70}$ Judgment of 23 November 2006, Asnef-Equifax v. Asociación de Usuarios de Servicios Bancarios, C-238/05, EU:C:2006:734, paragraph 63.

${ }^{71}$ European Commission, Case M.8124, Microsoft/LinkedIn, December 6, 2016, http://ec.europa.eu/ competition/mergers/cases/decisions/m8124_1349_5.pdf. The Commission affirmed that: “(350) Second, to the extent that these foreclosure effects would lead to the marginalisation of an existing competitor which offers a greater degree of privacy protection to users than LinkedIn (or make the entry of any such competitor more difficult), the Transaction would also restrict consumer choice in relation to this important parameter of competition when choosing a PSN". See, also, footnote 330: "The results of the market investigation have indeed revealed that privacy is an important parameter of competition and driver of customer choice in the market for PSN services (...). The finding of the importance of privacy as parameter of competition is consistent with the Commission's findings in Facebook/WhatsApp (...) in relation to consumer communication services".

${ }^{72}$ These remedies have behavioural nature and can be divided into two groups: integration Commitments and pre-installation Commitments. See: Michele Giannino, Microsoft/LinkedIn:
} 
However, the most expressive changes in perspective are verified in investigations of anti-competitive conducts, in particular abuse of dominant position, as will be detailed in the next item.

\section{Privacy violation as an abuse of dominant position?}

Initially, it is pertinent to highlight the position adopted by the Court of Justice of the European Union in the Allianz Hungaria Case. The Court recognised that an infringement of one area of law could possibly be a factor in deciding that there has been an infringement of competition law. In this regard, it would be possible that a breach of data protection law could constitute an infringement of competition law. ${ }^{73}$

Nevertheless, the most significant proceeding related with privacy opened by a European competition authority is the Bundeskartellamt's Facebook case ${ }^{74}$ in which the German authority considered Facebook's collection and use of data from third-party sources to be abusive and imposed on the company restrictions in the processing of user data. ${ }^{75}$

The relevant market was defined as the private social network market with private users in Germany. The Bundeskartellamt found that Facebook holds a dominant position, with a market share exceeding 95 per cent among daily active users.

Although the strongest evidence of a dominant position was the large market share of the company, the agency mentioned the ability to collect data as an element of its dominance. ${ }^{76}$

What the European Commission Said on the Competition Review of Digital Market Mergers (2017), 1, https://papers.ssrn.com/sol3/papers.cfm?abstract_id=3005299.

${ }^{73}$ Judgment of 14 March 2013, Allianz Hungaria and Generali-Providencia, C-32/11, ECLI:EU:C:2013:160.

${ }^{74}$ Jay Modrall, "Big data and merger control in the EU", Journal of European Competition Law \& Practice 9, no. 9 (2018): 569, https://doi.org/10.1093/jeclap/lpy062. The author highlights the following initiatives beyond German investigation: "EU antitrust authorities have taken a leading role in exploring antitrust concerns around 'big data'. The UK CMA announced the formation of a new technology team to keep pace with the use of algorithms, artificial intelligence and big data in 2017, and the French and German authorities published a joint study on big data and antitrust in 2016. Compared to these national authorities, the European Commission has kept a relatively low profile, although Commissioner Vestager has commented on big data and algorithm issues in several speeches".

${ }^{75}$ Bundeskartellamt, Case Summary, B6-22/16, Facebook, Exploitative business terms pursuant to Section 19(1) GWB for inadequate data processing. 15 February 2019. https://www.bundeskartellamt.de/SharedDocs/Entscheidung/EN/Fallberichte/Missbrauchsaufsicht/2019/B6-22-16. html?nn=3600108.

${ }^{76}$ Bundeskartellamt, Background Information on the Facebook Proceeding, 19 December, 2017, 2. https://www.bundeskartellamt.de/SharedDocs/Publikation/EN/Diskussions_ 
The German authority understood Facebook benefits from the "identity-based network effects", because users' criteria for the choice of a social network are its size and the possibility to find the persons they want to be in contact with on it. As a result, it is extremely difficult for consumers to switch to another social network (lock-in effect).

There is also an indirect network effect favourable to Facebook: advertisers prefer platforms with large numbers of users. Therefore, a competitor has to reach a large number of consumers to be attractive to the advertising side, a task that is almost impossible on account of the identitybased network effects. Consequently, Facebook has a quasi-monopoly in Germany, with a market share exceeding 95 per cent among daily active users. The Agency also found that there are strong barriers to market entry for a competitor, especially the comprehensive data sources. As a result of these combined factors, competitors have been experiencing a continuous decrease in user-based market shares over the years, and some of them have already left the relevant market. ${ }^{77}$

Facebook's large dominance of the relevant market is a central aspect of the case on account of the absence of alternatives to consumers. The Bundeskartellamt considered Facebook abuses its dominant position by imposing unfair terms of use to its consumers: they must choose between accepting "the whole Facebook package", including an extensive disclosure of personal data, or not using Facebook at all. Social network users are locked, because there is no parallel use of social networks in Germany. If they want to use such kind of service, they must be Facebook consumers and have no other option but to agree to unfair contractual terms.

The Bundeskartellamt focused only on data obtained from third party sources, which include firstly services owned by Facebook such as WhatsApp or Instagram, and secondly websites and apps of other operators with embedded Facebook APIs (Application Programming Interfaces).

The German authority found that "if a third-party website has embedded Facebook products such as the 'like' button or a 'Facebook login' option or analytical services such as 'Facebook Analytics', data will be transmitted

\footnotetext{
Hintergrundpapiere/2017/Hintergrundpapier_Facebook.html. The antitrust agency affirmed that: "Facebook has superior access to the personal data of its users and other competition-relevant data. Because social networks are data-driven products, access to such data is an essential factor for competition in the market. The data are relevant for both the product design and the possibility to monetise the service. If other companies lack access to comparable data resources, this can be an additional barrier to market entry".

${ }^{77}$ Bundeskartellamt, Case Summary, 6.
} 
to Facebook via APIs the moment the user calls up that third party's website for the first time". Even if the user has blocked web tracking in his browser or device settings, the data collected from third parties can be merged with data from the user's Facebook account. ${ }^{78}$

According to the Bundeskartellamt, consumers must accept the terms and conditions imposed by Facebook to access the service. In other words, the acceptance of Facebook's data policy is mandatory. In this regard, there is a violation of the data protection legislation, which requires the voluntary consumer consent to the collection and processing of data. ${ }^{79}$

Consequently, Facebook's terms and conditions are neither justified under data protection principles nor appropriate under competition law standards. The Bundeskartellamt understands that if a dominant company imposes consumers' consent to data collection and processing as a condition to contract the service, this can be taken as a case of "exploitative business terms", which constitutes an abuse of a dominant position to the detriment of both private users and competitors.

The Bundeskartellamt asserted that the dominant company should not practice unfair conduct against its users even if they do not pay a monetary price. The German antitrust authority considered that the damage to consumers would be the loss of control over the use of their personal data. ${ }^{80}$

At the time of the initiation of the proceeding, the Bundeskartellamt explained that a sole violation of data protection law without a direct and close connection with the existing dominant position on the market would not constitute an infringement of competition law. Therefore, a mere existence of unfair terms is not enough to characterise a competition infringement, the demonstration of a dominant position connected with the imposition of abusive contractual clauses being, thus, necessary. ${ }^{81}$

\footnotetext{
${ }^{78}$ Bundeskartellamt, Background Information on the Facebook Proceeding, 2.

${ }^{79}$ Bundeskartellamt, Case Summary, 10-11. The German authority affirmed that: "There is no effective consent pursuant to Art. 6(1a) of the GDPR. The reasons for this include the fact that, in view of Facebook's dominant position in the market, users consent to Facebook's terms and conditions for the sole purpose of concluding the contract, which cannot be assessed as their free consent within the meaning of the GDPR".

${ }^{80}$ Bundeskartellamt, Background Information on the Facebook Proceeding, 4. The authority stated that: "Facebook offers its service for free. Its users therefore do not suffer a direct financial loss from the fact that Facebook uses exploitative business terms. The damage for the users lies in a loss of control: they are no longer able to control how their personal data are used".

${ }^{81}$ Bundeskartellamt initiates proceeding against Facebook on suspicion of having abused its market power by infringing data protection rules. March 2, 2016. https://www.bundeskartellamt.de/ SharedDocs/Meldung/EN/Pressemitteilungen/2016/02_03_2016_Facebook.html.
} 
From a competition point of view, the Bundeskartellamt took into account the following elements: 1 - the dominant position of Facebook; 2 - data accumulation as a competitive differentiation that strengthens such dominance; and 3 - the imposition of an unfair privacy policy by Facebook. ${ }^{82}$ The German Federal Cartel Agency therefore concluded that the conduct could be considered as a case of "exploitative business terms", which is a type of abuse of dominant position under section 19(1) of the German competition law (GWB). ${ }^{83}$

The Bundeskartellamt based its decision on case law of the German Federal Court of Justice, which stated that the imposition of unfair terms by a company with market power is a hypothesis of abuse of a dominant position. ${ }^{84}$

The German antitrust authority has prohibited the data processing policy imposed by Facebook on its users and determined the termination of this conduct. The Bundeskartellamt has also ordered Facebook to implement the necessary changes and to adapt its data and cookie policies accordingly within a period of twelve months. ${ }^{85}$

A pertinent clarification is that the decision was formulated under the German legal system and based on the case law of the competent national court, considering the specificities of the proceeding.

\footnotetext{
${ }^{82}$ Giuseppe Colangelo and Mariateresa Maggiolino, "Data accumulation and the privacy-antitrust interface: Insights from the Facebook case for the EU and the U.S.", TTLF Working Paper no. 31 (2018), 15, https://papers.ssrn.com/sol3/papers.cfm?abstract_id=3125490. The authors explained that: "As a matter of law, aside from any privacy concerns, the Bundeskartellamt is concerned with two antitrust issues. First, it claims that this accumulation of data is allowing Facebook to entrench its dominant position: Facebook "can use [these data] to optimize its offer and tie more users to its network [...] to the detriment of other providers of social networks"; and Facebook "is becoming more and more indispensable for advertising customers [...with...] [a] potential for competitive harm on the side of the advertising customers". Second, the GCA alleges that the Facebook's request for a single catch-all grant of consent is unfair within the meaning of Article 102(a)".

${ }^{83}$ Section 19(1) of the German Act against Restraints of Competition (GWB) establishes: "The abuse of a dominant position by one or several undertakings is prohibited".

${ }^{84}$ The German Federal Court of Justice decided that an imposition of terms and conditions of contract that violate Sections of the German Civil Code by a company with market power is also an infringement of section 19 (1) of GWB (See: BGH, judgment of 6 November 2013 - KZR 58/11, BGHZ 199, 1, margin no. 65 - VBL-Gegenwert).

${ }^{85}$ Bundeskartellamt. Case Summary, 12. The prohibition refers to "the terms that involve the collection of user and device related data from other corporate services and Facebook Business Tools without the users' consent and their combination with Facebook data for purposes related to the social network".
} 
Given this caveat, it is important to emphasise that the imposition of unfair trading conditions is one of the hypotheses of abuse of a dominant position established by Article 102 TFEU. ${ }^{86}$ However, there have been only a few precedents of European Commission's proceedings linked to this legal disposition. In fact, the investigation of exploitative conducts has not been a priority for the European Commission in the enforcement of Article 102 TFEU. ${ }^{87}$

The Facebook case represents a significant change in perspective in competition law enforcement: the Bundeskartellamt has interpreted that under certain circumstances the violation of data protection rules by a company with market dominance could be considered as an abuse of dominant position.

Another remarkable aspect of the investigation is that the competition authority focused on the zero-price side of the market, i.e., the social network users. Precisely the opposite of the European Commission's analysis of the Google/DoubleClick case, which focused exclusively on the side of advertisers. ${ }^{88}$

Nevertheless, the Bundeskartellamt decision is very controversial, being subject to criticism because it would be an erroneous application of competition law to protect personal data. ${ }^{89}$

On the other hand, a comprehensive approach to big data concerns is supported by the European Data Protection Supervisor, who suggests a closer cooperation between data protection, consumer protection and antitrust authorities in the investigation and enforcement of personal data protection rules. The data authority urges for "a new concept of consumer

\footnotetext{
${ }^{86}$ Article 102 TFEU establishes that: "Any abuse by one or more undertakings of a dominant position within the internal market or in a substantial part of it shall be prohibited as incompatible with the internal market in so far as it may affect trade between Member States. Such abuse may, in particular, consist in: (a) directly or indirectly imposing unfair purchase or selling prices or other unfair trading conditions".

${ }^{87}$ See: European Commission, Guidance on the Commission's Enforcement Priorities in Applying Art. 82 of the EC Treaty to Abusive Exclusionary Conduct by Dominant Undertakings (2009/C 45/02), February 24, 2009, http://ec.europa.eu/competition/antitrust/art82/.

${ }^{88}$ Giulia Schneider, "Testing art. 102 TFEU in the digital marketplace: Insights from the Bundeskartellamt's investigation against Facebook", Journal of European Competition Law \& Practice 9, no. 4 (2018): 214, https://doi.org/10.1093/jeclap/lpy016.

${ }^{89}$ See, for example: Dirk Auer, "The FCO's Facebook Decision: Putting privacy before competition", CPI EU News: FCO Facebook Quadriptych (March, 2019): 1-5. https://www.competitionpolicyinternational.com/cpi-eu-news-fco-facebook-quadriptych/\#_edn4.
} 
harm for competition enforcement in digital economy" which represses "opaque or misleading privacy policies". 90

The joint report by the Autorité de la Concurrence and the Bundeskartellamt sustains that privacy issues cannot be excluded from consideration under competition law simply by virtue of their nature. The lack of transparency on the collection and processing of personal data can have, in parallel, implications on competition dimension. Misleading privacy policies are likely to affect competition, especially when they are implemented by a dominant firm using data as a key input. ${ }^{91}$

In a recent report prepared for the Federal Government of Germany, German scholars analysed the dynamics of the market power exercised on digital economy and concluded that the proceeding opened by Bundeskartellamt against Facebook is a good example of adequate implementation of German competition law and policy. ${ }^{92}$

In this regard, there are strong arguments to consider the Bundeskartellamt's proceeding as a correct competition law enforcement to penalise a new anticompetitive conduct in the digital economy. ${ }^{93}$

However, other tools could be enforced to restrain unfair privacy policies. For example, the Italian Competition Authority (Autorità Garante della Concorrenza e del Mercato) imposed a fine of $€ 3$ million on WhatsApp because the messenger company forced its users to accept in full its new terms of use, specifically the provision to share their personal data with Facebook. WhatsApp induced its consumers to believe that without granting such consent they would not be able to use the service

\footnotetext{
${ }^{90}$ European Data Protection Supervisor, Privacy and Competitiveness in the Age of Big Data: The Interplay between Data Protection, Competition Law and Consumer Protection in the Digital Economy (2014). https://edps.europa.eu/sites/edp/files/publication/14-03-26_competitition_law_ big_data_en.pdf.

${ }^{91}$ Autorité de la Concurrence and Bundeskartellamt. Competition Law and Data (2016), 23. https://www.bundeskartellamt.de/SharedDocs/Publikation/DE/Berichte/Big\%20Data\%20Papier. pdf?__blob=publicationFile\&v=2.

${ }^{92}$ Heike Schweitzer et al., Modernising the Law on Abuse of Market Power: Report for the Federal Ministry for Economic Affairs and Energy, (September 17, 2018). https://papers.ssrn.com/sol3/ papers.cfm?abstract_id $=3250742$.

${ }^{93}$ Giulia Schneider, "Testing art. 102 TFEU in the digital marketplace: Insights from the Bundeskartellamt's investigation against Facebook". Journal of European Competition Law \& Practice 9, no. 4 (2018), 213-225. https://doi.org/10.1093/jeclap/lpy016. The author affirms that: "Far from bending competition law to a heterogeneous task of protecting user's personal data the BKA's investigation is a welcome attempt to identify and remedy novel anti-competitive behaviour in digital markets".
} 
anymore. The company did not inform consumers adequately that they could decide not to give their consent to share the information of their WhatsApp account with Facebook and still be able to use the application. The agency also closed a second investigation, this time concerning the alleged unfair nature of some contractual clauses included in WhatsApp Messenger's "Terms of Use", whose acceptance was imposed on its consumers. The authority imposed fines in the two investigations opened against WhatsApp for violations of the consumer code. ${ }^{94}$

These condemnations, however, could not be considered a change in perspective as in the Bundeskartellamt's investigation, on account that the Italian Competition Authority also has the task to enforce the Italian Consumer Code. In other words, the Italian authority based its decision to fine WhatsApp for unfair privacy policy on infringement of the Italian Consumer Code, instead of competition law..$^{95}$

In fact, the existence of convictions of Facebook by consumer protection authorities stimulates debates whether the enforcement of consumer or data protection legislation would be preferable to the use of competition law. ${ }^{96}$

The decision issued by the Bundeskartellamt against Facebook brings new elements to a controversial issue: would it be possible to consider the imposition of unfair privacy terms by a platform with market power as a hypothesis of abuse of dominant position?

Even if it is possible, there is an important supplementary question: would it be preferable to apply consumer or personal data protection legislation instead of competition law?

The answers to these questions depend on the analysis of each concrete case, as well as of the legislation of each country investigating the conduct.

Anyway, it seems pertinent to adopt a comprehensive approach to privacy concerns, trying to harmonise competition enforcement and consumer

\footnotetext{
${ }^{94}$ Autorità Garante della Concorrenza e del Mercato. PS10601 CV154 - Sanzione da 3 milioni di euro per WhatsApp, ha indotto gli utenti a condividere i loro dati con Facebook, May 12, 2017, http:// www.agcm.it/media/comunicati-stampa/2017/5/alias-8754.

${ }^{95}$ Giuseppe Colangelo and Mariateresa Maggiolino, "Data accumulation and the privacy-antitrust interface: Insights from the Facebook Case for the EU and the U.S.", 28.

${ }^{96}$ See: Renato Nazzini, "Privacy and Antitrust: Searching for the (hopefully not yet lost) soul of competition law in the EU after the German Facebook Decision", CPI EU News: FCO Facebook Quadriptych (March, 2019): 1-8, https://www.competitionpolicyinternational.com/cpi-eu-newsfco-facebook-quadriptych/\#_edn4.
} 
and data protection polices in order to choose the proper way to protect the users of platforms with a dominant position.

Therefore, it is important to improve and enrich traditional antitrust concepts and tools in order to enhance the role of competition law to maximise the benefits of data-driven economy.

\section{Bibliography}

Andreu, Javier, Carmen Poon, Robert D. Merrifield, Stephen Wong, and Guang-Zhong Yang. "Big data for health". IEEE Journal of Biomedical and Health Informatics 19, no. 4 (2015): 1193-1208.

Armstrong, Mark. "Competition in two-sided markets”. RAND Journal of Economics 37, no. 3 (2006): 668-691.

Auer, Dirk. “The FCO's Facebook Decision: Putting privacy before competition”. CPI EU News: FCO Facebook Quadriptych (March, 2019): 1-5. https://www.competitionpolicyinternational.com/cpi-eu-news-fco-facebook-quadriptych/\#_edn4.

Autorità Garante della Concorrenza e del Mercato. PS10601 CV154 - Sanzione da 3 Milioni di Euro per WhatsApp, Ha Indotto gli Utenti a Condividere i Loro Dati con Facebook. May 12, 2017. http://www.agcm.it/media/comunicati-stampa/2017/5/alias-8754.

Autorité de la Concurrence and Bundeskartellamt. Competition Law and Data (2016). https://www.bundeskartellamt.de/SharedDocs/Publikation/DE/Berichte/Big\%20 Data\%20Papier.pdf?_blob=publicationFile\&v=2.

Averitt, Neil W. and Robert H. Lande. “Using the 'consumer choice approach' to antitrust law". Antitrust Law Journal 74 (2007): 175-264.

Bourreau, Marc, Alexandre de Streel and Inge Graef. "Big data and competition policy: Market power, personalised pricing and advertising". Centre on Regulation in Europe (February 16, 2017): 7-61. https://ssrn.com/abstract=2920301.

Boyd, Danah and Kate Crawford. "Six provocations for big data". A Decade in Internet Time: Symposium on the Dynamics of the Internet and Society, September 21, 2011. https://ssrn.com/abstract=1926431 or http://dx.doi.org/10.2139/ssrn.1926431.

Bundeskartellamt. Background Information on the Facebook Proceeding, December 19, 2017, 1-6. https://www.bundeskartellamt.de/SharedDocs/Publikation/EN/Diskussions _Hintergrundpapiere/2017/Hintergrundpapier_Facebook.html.

Bundeskartellamt. Case Summary. B6-22/16. Facebook, Exploitative business terms pursuant to Section 19(1) GWB for inadequate data processing. 15 February 2019. https://www.bundeskartellamt.de/SharedDocs/Entscheidung/EN/Fallberichte/ Missbrauchsaufsicht/2019/B6-22-16.html?nn=3600108.

Bundeskartellamt. Preliminary Assessment in Facebook Proceeding: Facebook's Collection and Use of Data from Third-Party Sources is Abusive. December 19, 2017. https://www. 
bundeskartellamt.de/SharedDocs/Meldung/EN/Pressemitteilungen/2017/19_12_2017_ Facebook.html.

Burkhardt, Beiten. "The new German competition law in a nutshell”. Lexology. June 26, 2017. https://www.lexology.com/library/detail.aspx?g=535d2bda-4598-413d-86c605b592b1c7b5.

Cavoukian, Ann. Privacy by Design in Law, Policy and Practice: A White Paper for Regulators, Decision-Makers and Policy-Makers, 2011. http://www.ontla.on.ca/library /repository/mon/25008/312239.pdf.

Colangelo, Giuseppe and Mariateresa Maggiolino. "Data accumulation and the privacyantitrust interface: Insights from the Facebook case for the EU and the U.S.". TTLF Working Paper no. 31 (2018): 1-48. https://papers.ssrn.com/sol3/papers.cfm?abstract _id=3125490.

Conselho Administrativo de Defesa Econômica. Guia para Análise de Atos de Concent ração Horizontal, 2006. http://www.cade.gov.br/acesso-a-informacao/publicacoesinstitucionais/guias_do_Cade/guia-para-analise-de-atos-de-concentracao-horizontal.pdf/view.

Curry, Edward. "The big data value chain: Definitions, concepts, and theoretical approaches". In New Horizons for a Data-Driven Economy, edited by José Maria Cavanillas, Edward Curry and Wolfgang Wahlster, 29-38. Switzerland: Springer, 2016.

De Mauro, Andrea, Mauro Greco and Micheli Grimaldi. "What is big data? A consensual definition and a review of a key research topics". 4th International Conference on Integrated Information (2014): 1-11. https://www.researchgate.net/publication/265775800_What_is_Big_Data_A_Consensual_Definition_and_a_Review_ of_Key_Research_Topics.

Eilmansberger, Thomas. "How to distinguish good from bad competition under article 82 EC: In search of clearer and more coherent standards for anti-competitive abuses". Common Market Law Review 42 (2005): 129-177.

European Commission. Case M.7217. Facebook/WhatsApp. October 3, 2014 http:// ec.europa.eu/competition/mergers/cases/decisions/m7217_20141003_20310_ 3962132_EN.pdf.

European Commission. Case M.8124. Microsoft/LinkedIn. December 6, 2016. http:// ec.europa.eu/competition/mergers/cases/decisions/m8124_1349_5.pdf.

European Commission. Fact Sheet Data cPPP. https://ec.europa.eu/research/ industrial_technologies/pdf/factsheet-cppp_en.pdf.

European Commission. Guidance on the Commission's Enforcement Priorities in Applying Art. 82 of the EC Treaty to Abusive Exclusionary Conduct by Dominant Undertakings (2009/C 45/02). February 24, 2009. http://ec.europa.eu/competition/ antitrust/art82/. 
European Commission. Guidelines on the Assessment of Horizontal Mergers under the Council Regulation on the Control of Concentrations between Undertakings (2004/C 31/03). February 2, 2004. https://eur-lex.europa.eu/legal-content/EN/ALL/?uri=CEL EX\%3A52004XC0205\%2802\%29.

European Commission. The EU Data Protection Reform and Big Data. March 2016. https://ec.europa.eu/epsc/publications/strategic-notes/enter-data-economy_en.

European Commission. Towards a Thriving Data-Driven Economy, COM (2014) 442, July 2, 2014, 4. https://ec.europa.eu/digitalagenda/en/news/communication -data-driven-economy.

Evans, David S. "Attention to rivalry among online platforms and its implications for antitrust analysis". Coase-Sandor Institute for Law \& Economics Working Paper no. 627, (2013): 1-42. https://chicagounbound.uchicago.edu/law_and_economics/68/.

Evans, David S. "Some empirical aspects of multi-sided platform industries". Review of Network Economics 2, no. 3 (2003): 191-209.

Evans, David S. "The online advertising industry: Economics, evolution, and privacy". The Journal of Economic Perspectives 23, no. 3 (2009): 37-60.

Federal Trade Commission. Revised Jurisdictional Thresholds for Section 7A of the Clayton Act. January 29, 2018. https://www.ftc.gov/system/files/documents/federal_register_ notices/2018/01/revised_jurisdiction_7a_1-29-18.pdf.

Filistrucchi, Lapo, Damien Geradin, and Eric Van Damme. "Identifying two-sided markets". TILEC Discussion Paper no. 2012-008 (2012): 1-25. https://ssrn.com/ abstract=2008661.

Forgioni, Paula. Os Fundamentos do Antitruste. São Paulo: Revista dos Tribunais, 2018. Frazão, Ana. "Big data e impactos sobre a análise concorrencial: Preocupações que já se vislumbram no cenário atual”. Jota, February 7, 2018. https://www.jota. info/?pagename=paywall\&redirect_to=//www.jota.info/opiniao-e-analise/colunas/ constituicao-empresa-e-mercado/big-data-e-impactos-sobre-analise-concorrencial-2-07022018.

Giannino, Michele. Microsoft/LinkedIn: What the European Commission Said on the Competition Review of Digital Market Mergers (2017): 1-17. https://papers.ssrn.com/ sol3/papers.cfm?abstract_id=3005299.

Grunes, Allen P. and Maurice E. Stucke. "No mistake about it: The important role of antitrust in the era of big data". University of Tennessee Legal Studies Research Paper no. 269 (2015). https://ssrn.com/abstract=2600051.

Harbour, Pamela Jones and Tara Isa Koslov. "Section 2 in a Web 2.0 World: An expanded vision of relevant product markets”, Antitrust Law Journal 76 (2010): 769-797.

Hazen, Benjamin T., Christopher A. Boone, Jeremy D. Ezell and L. Allison JonesFarmer. "Data quality for data science, predictive analytics, and big data in supply 
chain management: An introduction to the problem and suggestions for research and applications". International Journal of Productions Economics 154 (2014): 72-80. https://www.sciencedirect.com/science/article/pii/S0925527314001339?via\%3Dihub.

Hilbert, Martin and Priscila López. “The world's technological capacity to store, communicate, and compute information”. Science 332, no. 6025 (2011): 60-65. http://science.sciencemag.org/content/332/6025/60.full.

Khan, Lina. “Amazon's antitrust paradox". Yale Law Journal 126, no. 3 (2016-2017): 712 805. https://www.yalelawjournal.org/pdf/e.710.Khan.805_zuvfyyeh.pdf.

Martens, Bertin. "An economic policy perspective on online platforms". Institute for Prospective Technological Studies Digital Economy Working Paper 2016/05 (2016): 1-60. https://ec.europa.eu/jrc/sites/jrcsh/files/JRC101501.pdf.

McAfee, Andrew and Erik Brynjolfsson. "Big data: The management revolution". Harvard Business Review 90, no. 10 (2012): 60-68.

Miller, H. Gilbert and Peter Mork. "From data to decisions: A value chain for big data”. IT Professional 15, no. 1 (2013): 57-59. https://www.researchgate.net/ publication/260305818_From_Data_to_Decisions_A_Value_Chain_for_Big_Data.

Modrall, Jay. "Big data and merger control in the EU". Journal of European Competition Law \& Practice 9, no. 9 (2018): 569-578.

Morando, Federico, Raimondo Iemma, and Emilio Raiteri. "Privacy evaluation: What empirical research on users' valuation of personal data tells us". Internet Policy Review 3, no. 2 (2014). https://policyreview.info/articles/analysis/privacy-evaluation -what-empirical-research-users-valuation-personal-data-tells-us.

Nazzini, Renato. "Privacy and Antitrust: Searching for the (hopefully not yet lost) soul of competition law in the EU after the German Facebook Decision". CPI EU News: FCO Facebook Quadriptych (March, 2019): 1-8. https://www.competitionpolicyinternational.com/cpi-eu-news-fco-facebook-quadriptych/\#_edn4.

Newman, John M. “Antitrust in zero-price markets: Foundations". University of Pennsylvania Law Review 164, no. 1 (2015): 149-206.

OECD. Algorithms and Collusion: Competition Policy in the Digital Age, 2017. www.oecd. org/competition/algorithms-collusion-competition-policy-in-the-digital-age.htm.

OECD. Data-Driven Innovation for Growth and Well-Being Interim Synthesis Report, 2017. http://www.oecd.org/sti/inno/data-driven-innovation-interim-synthesis.pdf.

Office of Fair Trade. Assessment of Market Power. December 1st, 2004. https://assets. publishing.service.gov.uk/government/uploads/system/uploads/attachment_data/ file/284400/oft415.pdf.

Office of Fair Trade. Completed Acquisition by Motorola Mobility Holding (Google, Inc.) of Waze Mobile Limited. ME/6167/13. November 11, 2013. https://assets.publishing. service.gov.uk/media/555de2cfed915d7ae2000027/motorola.pdf. 
Ohlhausen, Maureen K., and Alexander P. Okuliar. "Competition, consumer protection and the right (approach) to privacy”. Antitrust Law Journal 80, no. 1 (2015): 121-156.

Petit, Nicolas. "From formalism to effects? The Commission's communication on enforcement priorities in applying Article 82 EC". World Competition: Law and Economics Review, forthcoming (2009): 1-19. https://ssrn.com/abstract=1476082.

Pittman, Russell W. "Consumer surplus as the appropriate standard for antitrust enforcement”. Competition Policy International 3, no. 2 (2007): 205-224. https://ssrn. com/abstract $=1075463$.

Rubinfeld, Daniel L. and Michal S. Gal. “The hidden costs of free goods: Implications for antitrust enforcement”. Antitrust Law Journal 80 (2016): 521-562.

Rust, Roland T., Kannan P. K., and N. Peng. "The customer economics of internet privacy". Journal of the Academy of Marketing Science 30 (2002): 455-464.

Savage, Scott J. and Donald M. Waldman. "Privacy tradeoffs in smartphone applications”. Economic Letters 137 (2015): 171-175.

Schneider, Giulia. "Testing art. 102 TFEU in the digital marketplace: Insights from the Bundeskartellamt's investigation against Facebook". Journal of European Competition Law \& Practice 9, no. 4 (2018): 213-225. https://doi.org/10.1093/jeclap/lpy016.

Schweitzer, Heike, Justus Haucap, Wolfgang Kerber, and Robert Welker. Modernising the Law on Abuse of Market Power: Report for the Federal Ministry for Economic Affairs and Energy. September 17, 2018. https://papers.ssrn.com/sol3/papers. cfm?abstract_id=3250742.

Shelanski, Howard A. "Information, innovation, and competition policy for the internet”. University of Pennsylvania Law Review 161 (2013): 1663-1678.

Sokol, D. Daniel and Roisin E. Comerford. "Antitrust and regulating big data". George Mason Law Review 23, no. 5 (2016): 1129-1162.

Stucke, Maurice E. and Allen P. Grunes. Big Data and Competition Policy. Oxford: Oxford University Press, 2016.

Stucke, Maurice E. and Ariel Ezrachi. "Looking up in the data-driven economy". University of Tennessee Legal Studies Research Paper 333 (2017): 1-6. https://ssrn.com/ abstract $=2975510$.

Tirole, Jean. Economics for the Common Goods. Princeton: Princeton University Press, 2017.

Tucker, Catherine. "The implications of improved attribution and measurability for antitrust and privacy in online advertising markets". George Mason Law Review 20, no. 4 (2013): 1025-1034.

Tucker, Darren S. and Hill Wellford. "Big mistakes regarding big data". The Antitrust Source (December 2014): 1-12. https://www.americanbar.org/content/dam/aba/publishing/antitrust_source/dec14_tucker_12_16f.authcheckdam.pdf. 
Vezzoso, Simonetta. "Competition policy in a world of big data". In Research Handbook on Digital Transformations, edited by F. Xavier Olleros and Majlinda Zhegu, 400-420. Cheltenham: Edward Elgar, 2016. https://ssrn.com/abstract=2717497.

Wu, Tim. "Blind spot: The attention economy and the law". Antitrust Law Journal, forthcoming (2017): 2-40, https://scholarship.law.columbia.edu/faculty_scholarship/2029.

Wu, Tim. "It's time to break up Facebook". The Verge. April 9th, 2018. https://www. theverge.com/2018/9/4/17816572/tim-wu-facebook-regulation-interview-curse -of-bigness-antitruste.

Wu, Tim. The Attention Merchants: The Epic Scramble to Get Inside Our Heads. New York: Alfred A. Knopf, 2016. 